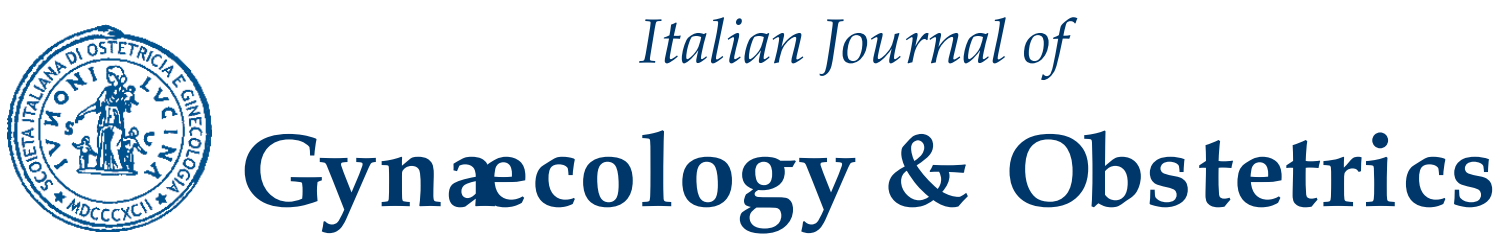

June 2020 - Vol. 32 - N. 2 - Quarterly - ISSN 2385 - 0868

\title{
In vitro fertilization and psychological stress: new insight about different routes of progesterone administration
}

\author{
D. Mele, F. Caprio, M.D. D’Eufemia, A. Schiattarella, D. Labriola, M.T. Schettino, N. Colacurci \\ Department of Woman, Child and General and Specialized Surgery, University of Campania \\ "Luigi Vanvitelli", Naples, Italy
}

\section{ABSTRACT}

Infertility treatment is a stressful process and factors like anxiety and preoccupation could affect the success of In Vitro Fertilization (IVF) or other assisted reproductive techniques. Moreover, luteal phase support (LPS) in IVF cycles is recommended. Our aim was to analyze the effects of LPS with intramuscular and subcutaneous progesterone on stress hormones (cortisol and prolactin). We analyzed one hundred-thirty women undergoing their first IVF cycle and then randomized in two groups: group A (65 patients) received $33 \mathrm{mg} /$ day of intramuscular in oil-progesterone from pick-up and 50mg/day from embryo transfer, group B (65 patients), instead, received $25 \mathrm{mg}$ of subcutaneous water soluble-progesterone from pick-up. Cortisol and prolactin serum levels were obtained at day +7 from oocyte retrieval. Our results showed that the values of prolactin and cortisol were statistically significantly higher in group A compared to the group B. Subcutaneous progesterone treatment, in fact, is associated with lower cortisol and prolactin levels, suggesting new therapeutic opportunities in IVF cycles to reduce patients' distress and improve quality of life.

Corresponding Author: Antonio Schiattarella aschiattarella@gmail.com

\section{SOMMARIO}

Il trattamento dell'infertilità è un processo stressante e fattori come l'ansia e la preoccupazione potrebbero influenzare il successo della fecondazione in vitro (IVF) o di altre tecniche di riproduzione assistita. Inoltre, il supporto alla fase luteale (LPS) è raccomandato nei cicli di IVF. Il nostro obiettivo è stato quello di analizzare gli effetti sugli ormoni dello stress (cortisolo e prolattina), della LPS con progesterone intramuscolare e sottocutaneo. Abbiamo analizzato centotrenta donne sottoposte al primo ciclo di IVF e le abbiamo randomizzate in due gruppi: il gruppo A (65 pazienti) ha ricevuto $33 \mathrm{mg} /$ die di progesterone intramuscolare dal giorno del pick-up e $50 \mathrm{mg} /$ die dal giorno del trasferimento dell'embrione, il gruppo B (65 pazienti), invece, ha ricevuto $25 \mathrm{mg}$ di progesterone, solubile in acqua, per via sottocutanea dal giorno del pick-up. I livelli sierici di cortisolo e prolattina sono stati valutati dopo sette giorni dal pick-up. I nostri risultati hanno mostrato che i valori di prolattina e cortisolo erano statisticamente più alti nel gruppo A rispetto al gruppo B. Il trattamento sottocutaneo di progesterone, infatti, è associato a livelli più bassi di cortisolo e prolattina, suggerendo nuove opportunità terapeutiche nei cicli di IVF per ridurre lo stress dei pazienti e migliorare la qualità della vita.
Key words: IVF; cortisol; prolactin; luteal phase support; pregnancy; progesterone 


\section{INTRODUCTION}

The diagnosis of infertility is a stressful event for the couple and may cause negative symptoms such as depression, anxiety and psychosomatic symptoms, potentially interfering with the medical procedures. Different types of psychological stressors in humans are related to an increased serum levels of the anterior pituitary hormone prolactin (PRL) and to an activation of the hypothalamic-pituitary-adrenal (HPA) axis with the synthesis and release of cortisol (CORT) by the adrenal cortex (1). Such adaptive mechanisms allow the body to maintain physiological stability. Therefore, PRL and CORT can be considered stress biomarkers. In vitro fertilization (IVF) represents the treatment of choice for over 1.000.000 infertile couples each year (2), and among infertility treatment it is the most stressful and emotionally demanding procedure because of daily injections, blood draws, ultrasound checks, oocyte retrieval, and the possible failure of the cycle $(3,4,5)$. The role of stress in IVF has long been a topic of interest. Questions include whether the process of fertility treatment is stressful, whether stress or anxiety has an impact on success of fertility treatment, and whether interventions to decrease stress are useful $(6,7)$. The perception that psychological stress may prevent a woman from attaining and maintaining a pregnancy has become widely accepted (8-12). Besides, other authors suggest that couples entering an IVF-treatment program are usually psychologically well-adjusted (3). Moreover, women's anxiety and general distress change during the course of one treatment cycle: a pioneering study (8) monitored the entire course of the IVF treatment cycle by daily record of subjective general distress and reported a significant increased distress at the end of the cycle, between oocyte retrieval and pregnancy test. Such data were confirmed by other studies $(8,13-16)$. IVF cycles are associated with abnormal luteal phase leading to poor endometrial development and asynchrony of endometrial receptivity, therefore a pharmacological support is recommended $(17,18)$. Progesterone for luteal phase support (LPS) is available for intramuscular (IM) injection in oil, for vaginal preparation, either in oil-capsule or vaginal gel, and for oral capsule. Recently, a water-soluble injectable progesterone has become available for subcutaneous (SC) injection. The purpose of this study was to investigate the effects of LPS with IM and SC progesterone on the stress hormones (CORT and PRL) that are known to influence reproductive outcomes in IVF cycles.

\section{MATERIALS AND METHODS}

This was a prospective study of women undergoing their first IVF treatment for primary infertility, between March 2017-October 2017, to the Department of Obstetrics and Gynecology of University of Campania "Luigi Vanvitelli" in Naples (Italy). All patients signed informed consent form to be part of a study. The experimental study was conducted in accordance with principles of the Helsinki Declaration of 1975, using routine clinical practice procedures usually performed during IVF cycles; such procedures did not involve additional risks to the patients and all the medical decisions concerning individual patients were not affected by the study. The study was approved by Local Review Board. All the women were $<37$ years old, showed regular menstrual cycles, body mass index (BMI) between 20 and $25 \mathrm{~kg} / \mathrm{m} 2$, serum hormonal profile within the normal range $(\mathrm{FSH}$ and $\mathrm{LH}<10$ $\mathrm{IU} / \mathrm{ml}$, E2 $<50 \mathrm{pg} / \mathrm{ml}$, prolactin $<30 \mathrm{ng} / \mathrm{ml}$ ), normal karyotype, normal uterine cavity as diagnosed at ultrasonographic and hysteroscopy examination. Exclusion criteria were: acute illness, chronic disorders, PCOs, endometriosis, organic dysfunction. Patients included in the study underwent ovarian stimulation with our standard protocol. Briefly, all the patients underwent a standard down-regulation with $\mathrm{GnRH}$ analogue hormone at a dose of $0.1 \mathrm{mg} /$ day (Triptoreline, Decapeptyl, Ipsen, Milan, Italy) until estradiol levels $\geq 40 \mathrm{ng} / \mathrm{mL}$ and no follicle $>7$ $\mathrm{mm}$; patients over 35 years old received a sequential stimulation protocol starting with uFSH (Fostimon, IBSA, Switzerland) for 6 days according to a step-down approach (225IU for 4 days and 150 IU for the last two days) and then shifting to $\mathrm{rFSH}$ at the standard dosage of 150 IU; patients under 35 years old received a standard protocol with rFSH (Gonal- F; Serono, Rome, Italy), at a daily dose of 225 IU for 4 days and $150 I U$ for the last two days. By the seventh day therapy was personalized according to the hormonal and ultrasonographic assessment. 
Ovulation induction was monitored by vaginal ultrasound and hormonal assessment every second-third day. When at least three follicles had reached a diameter of $18 \mathrm{~mm}$, a single SC bolus of 10.000 IU of hCG (Gonasi HP 10000; IBSA, Rome, Italy) was administered. Transvaginal follicular aspiration was performed 34-36h after hCG administration. Oocytes retrieved were cultured in Petri dishes in IVF HTF Buffer (Cook Medical) at $37^{\circ} \mathrm{C}$ in a humidified $5 \%$ carbon dioxide/ $95 \%$ air environment. The oocytes were denuded enzymatically using $80 \mathrm{IU} / \mathrm{ml}$ hyaluronydase (Sage) and mechanically. The semen was processed with $90 \%-45 \%$ discontinuous Gradient (SAGE In-Vitro Fertilization) centrifugation at $1700 \mathrm{~g}$ for 12 minutes. After IVF, the resulting embryos were cultured in IVF Cleavage Medium (Cook Medical) at $37^{\circ} \mathrm{C}$ under $5 \%$ carbon dioxide in air environment until day +3 . At day +4 , we changed the culture media and used IVF Blastocyst Medium (Cook Medical) at $37^{\circ} \mathrm{C}$ under $5 \%$ carbon dioxide in air environment until the day of embryo transfer. Serum levels of hCG were measured 14 days after ET and, if positive, were obtained every 3-6 days until an intrauterine gestational sac was demonstrated by US examination. Until the pregnancy test, patients were invited to follow their usual lifestyle, workers were invited to continue their occupation. Patients were randomized in two groups according to the luteal phase support: group A (65 patients) received $33 \mathrm{mg} /$ day of IM in oilprogesterone starting from pick-up day and then $50 \mathrm{mg} /$ day from embryo transfer (ET) day, group B (65 patients) received $25 \mathrm{mg}$ of SC water soluble-progesterone from pick-up day. Blood samples for PRL e CORT dosage were obtained from all subjects at day +7 from oocyte retrieval by venipuncture in the morning between 7.30 and 8.30 and stored until analysis. PRL e CORT serum levels are very susceptible to multiple variables, like the time of blood collection, fasting state, protocol of stimulation. To reduce possibly bias, all patients had serum levels checked before 8.30 A.M. and were not fasting; all patients received low-dose aspirin by ET day. Blood serum levels for CORT and PRL detection were by Immunolite from DPC/Siemens (Princeton, NJ) (PRL intra-assay coefficient of variation [CV] 1/4 6.8\%; interassay CV 1/4 9.6\%; CORT intra-assay CV $1 / 48.8 \%$; inter-assay CV $1 / 410 \%)$. Data are shown as mean \pm standard deviation (SD). For statistical analysis, t-test, $\chi^{2}$, log rank analysis, and analysis of variance were used as appropriate. The results were statistically significant when $\mathrm{p}$-value was $<0.05$.

\section{RESULTS}

One-hundred thirty patients were enrolled for a prospective study. All patients completed IVF stimulation, egg retrieval, ET and performed a pregnancy test. Group A and B were similar concerning baseline characteristics and stimulation data (table I).

Table I. Baseline characteristics and stimulation data in two group.

\begin{tabular}{|c|c|c|c|}
\hline & $\begin{array}{c}\text { Group A } \\
(n=65)\end{array}$ & $\begin{array}{l}\text { Group B } \\
(n=65)\end{array}$ & p-value \\
\hline $\begin{array}{c}\text { Age } \\
\text { (years) }\end{array}$ & $33.2 \pm 2.8$ & $33.9 \pm 3.1$ & ns \\
\hline $\begin{array}{c}\text { Body mass } \\
\text { index } \\
(\mathrm{kg} / \mathrm{m} 2)\end{array}$ & $23.3 . \pm 2.3$ & $24.2 \pm 2.0$ & ns \\
\hline $\begin{array}{c}\text { Time } \\
\text { of } \\
\text { infertility } \\
\text { (years) }\end{array}$ & $1.9 \pm 1$ & $2.2 \pm 0.5$ & ns \\
\hline $\begin{array}{c}\text { Day-3 FSH } \\
(\mathrm{IU} / \mathrm{mL})\end{array}$ & $7.4 \pm 1.9$ & $6.9 \pm 2.3$ & ns \\
\hline $\begin{array}{c}\mathrm{AMH} \\
(\mathrm{ng} / \mathrm{mL})\end{array}$ & $2.3 \pm 1.1$ & $2.8 \pm 1.8$ & ns \\
\hline $\begin{array}{l}\text { Total dose } \\
\text { of } \\
\text { FSH used } \\
\text { (IU) }\end{array}$ & $2.098 .9 \pm 837.6$ & $2.122 .5 \pm 786.5$ & ns \\
\hline $\begin{array}{l}\text { Estradiol } \\
\text { on } \\
\text { hCG day } \\
\text { (pg/mL) }\end{array}$ & $1.872 \pm 684.6$ & 1.928.2 \pm 708.1 & ns \\
\hline
\end{tabular}

Abbreviations: $n s$, not significant

All patients had a regular lifestyle during LPS, reporting neither bleeding or spotting, nor any health problem. No statistically significant difference in number of oocyte retrieval, 
fertilization rate, number of transferred embryo and pregnancy rate were found among two group. The data were show in table II.

Table II - Data from IVF cycles.

\begin{tabular}{|c|c|c|c|}
\hline & $\begin{array}{c}\text { Group A } \\
(\mathbf{n}=65)\end{array}$ & $\begin{array}{c}\text { Group B } \\
(\mathbf{n}=\mathbf{6 5})\end{array}$ & p-value \\
\hline $\begin{array}{c}\text { Retrieved } \\
\text { oocytes (n) }\end{array}$ & $9.7 \pm 4.5$ & $10.2 \pm 3.9$ & ns \\
\hline $\begin{array}{c}\text { Metaphase II } \\
\text { oocytes (n) }\end{array}$ & $6.5 \pm 1.7$ & $6.7 \pm 1.6$ & $\mathrm{~ns}$ \\
\hline $\begin{array}{c}\text { Fertilization } \\
\text { rate (\%) }\end{array}$ & 85.7 & 83.8 & $\mathrm{~ns}$ \\
\hline $\begin{array}{c}\text { Transferred } \\
\text { embryo (n) }\end{array}$ & $2.6 \pm 0.3$ & $2.2 \pm 0.5$ & $\mathrm{~ns}$ \\
\hline $\begin{array}{c}\text { Pregnancy } \\
(\mathrm{n})\end{array}$ & 8 & 9 & $\mathrm{~ns}$ \\
\hline $\begin{array}{c}\text { Pregnancy } \\
\text { rate (\%) }\end{array}$ & 24.2 & 25.7 & $\mathrm{~ns}$ \\
\hline
\end{tabular}

Abbreviations: $n s$, not significan

The values of PRL and CORT were statistically significantly higher in group treated by IM route compared to the group treated by SC route ( 27.5 $\pm 3.3 \mathrm{ng} / \mathrm{ml}$ vs $21.8 \pm 3.3 \mathrm{ng} / \mathrm{ml}, 345.5 \pm 29.9$ $\mu \mathrm{g} / \mathrm{L}$ vs $310.5 \pm 28.7 \mu \mathrm{g} / \mathrm{L}$ ) (table III).

Table III - Values of Cortisol (COR) and Prolactin (PRL).

\begin{tabular}{|c|c|c|c|}
\hline & $\begin{array}{c}\text { Group A } \\
(\mathbf{n}=65)\end{array}$ & $\begin{array}{c}\text { Group B } \\
(\mathbf{n}=\mathbf{6 5})\end{array}$ & p-value \\
\hline $\begin{array}{c}\mathrm{COR} \\
(\mu \mathrm{g} / \mathrm{L})\end{array}$ & $345.5 \pm 29.9$ & $310.5 \pm 28.7$ & $<0.05$ \\
\hline $\begin{array}{c}\mathrm{PRL} \\
(\mathrm{ng} / \mathrm{ml})\end{array}$ & $27.5 \pm 3.3$ & $21.8 \pm 3.3$ & $<0.05$ \\
\hline
\end{tabular}

\section{DISCUSSION}

Many investigators discussed the role of stress on reproductive failure $(19,20,21)$. It is well demonstrated that the infertility and IVF are conditions of chronic stress, which is highlighted in the final stages of the cycle when the expectation becomes more intensive (22). Moreover, stress can favor Human Papillomavirus persistence, a sexually transmitted infection, that may affect fertility and alter the efficacy of assisted reproductive technologies (23-26). Many reports show that stress levels across stages of the IVF cycle vary between pregnant and non-pregnant women $(8,13-16,27)$. Perceived stress questionnaires are the most widely used psychological instrument for measuring the subjective perception of stress, but they may result unreliable: it is well known that infertile patients suppress their feelings of stress because they want to show the clinic that they are functioning well both socially and psychologically (28-30).

PRL and CORT may appropriately be used as objective indicators of stress levels.

Our data showed that treatment with SC progesterone is associated with statistically significant lower levels of CORT and PRL during the LPS of an IVF cycle. It can be speculated that patients showed higher compliance to SC route while are bothered by progesterone IM injection.

Since the SC route is a friendly administration already daily experienced by the patients during ovulation induction with gonadotropins, switching progesterone supplementation from IM to SC administration could modify the levels of stress markers (31-33). Moreover, IM progesterone administration may be burdened by local inflammation and pain and increased the dropout rate from the treatment, whereas SC route is less painful and is associate with a handily daily management of LPS $(12,34)$.

The patient should not manage anxiety related to a new type of administration and may selfmanage therapy remaining independent from another person. Moreover, SC administration allows the woman to face each injection with greater confidence and concern and to reduce the possibility of drop out at any stage of the present and possible future cycle.

In conclusion, a friendly route of administration may lead primarily to reduce levels of stress indicators such as PRL and CORT, then to improve patients' quality of life, to optimize therapeutic strategy as regards the IVF outcome, finally to reduce dropout rate from IVF program.

Our results suggest a new opportunity in IVF therapy to reduce patients distress and improve 
the quality of life, supporting the development of new research perspectives and new therapeutic strategy for the management of LPS during IVF.

\section{CONFLICT OF INTERESTS}

The authors declare that they have no conflict of interests. 


\section{REFERENCES}

(1) Belda X, Fuentes S, Daviu N, Nadal R, Armario A. Stress-induced sensitization: the hypothalamic-pituitary-adrenal axis and be-yond. Stress. 2015; 18(3): 269-79.

(2) Horsey K. Progress Educational Trust. 3,000,000 IVF Babies born worldwide since 1979.

Presented at the annual conference of the European Society of Human Reproduction and Embryology (ESHRE) 2006.

(3) Demyttenaere K, Nijs P, Evers-Kiebooms G, Koninckx PR. Coping and the ineffective-ness of coping influence the outcome of in vitro fertilization through stress responses. Psychoneuroendocrinology. 1992;17(6):655.

(4) Verhaak CM, Smeenk JM, van Minnen A, Kremer JA, Kraaimaat FW. A longitudinal, prospective study on emotional adjustment be-fore, during and after consecutive fertility treatment cycles. Hum Reprod. 2005; 20:2253.

(5) Campitiello MR, De Franciscis P, Mele D, Izzo G, Sinisi A, Delrio G, Colacurci N. Endometrial LGR7 expression during menstrual cycle. Fertil Steril 2011, 95 (8): 2511-2514.

(6) Seibel MM, Taymor ML. Emotional aspects of infertility. Fertil Steril. 1982; 37(2): 137.

(7) Barnea ER, Tal J. Stress-related reproduc-tive failure. J In Vitro Fert Embryo Transf. 1991; 8(1): 15.

(8) Boivin J, Takefman JE, Tulandi T, Brender W. Reactions to infertility based on extent of treatment failure. Fertil Steril. 1995; 63:801.

(9) Csemiczky G, Landgren BM, Collins A. The influence of stress and state anxiety on the outcome of IVF-treatment: psychological and endocrinological assessment of Swedish wom-en entering IVF-treatment. Acta Obstet Gyne-col Scand. 2000; 79(2): 113.

(10) Rocca ML, Venturella R, Mocciaro R, Di Cello A, Sacchinelli A, Russo V et al. Polycy-stic ovary syndrome: Chemical pharmacothe-rapy. Expert Opin Pharmacother. 2015; 16(9): 1369-93. (11) de Klerk C, Hunfeld JA, Heijnen EM, Ei-jkemans MJ, Fauser BC, Passchier J, Macklon NS. Low negative affect prior to treatment is associated with a decreased chance of live birth from a first IVF cycle. Hum Reprod. 2008; 23:112.

(12) An Y, Sun Z, Li L, Zhang Y, Ji H. Rela-tionship between psychological stress and re-productive outcome in women undergoing in vitro fertilization treatment: Psychological and neurohormonal assessment. J Assist Reprod Genet. 2013; 30:35-41.

(13) Merari D, Feldberg D, Elizur A, Goldman J, Modan B. Psychological and hormonal changes in the course of in vitro fertilization. J Assist Reprod Genet. 1992; 9(2): 161-9.

(14) Ardenti R, Campari C, Agazzi L, La-Sala GB. Anxiety and perceptive functioning of in-fertile women during in-vitro fertilization: Ex-ploratory survey of an Italian sample. Hum Reprod. 1999; 14: 3126.

(15) Yong P, Martin C, Thong J. A comparison of psychological functioning in women at dif-ferent stages of in vitro fertilization treatment using the mean affect adjective checklist. J As-sist Reprod Genet. 2000; 17:553

(16) Klonoff-Cohen $\mathrm{H}$, Chu E, Natarajan L, Sieber W. A prospective study of stress among women undergoing in vitro fertilization or gamete intrafallopian transfer. Fertil Steril. 2001; 76:675-87.

(17) Tavaniotou A, Albano C, Smitz J, Devro-ey P. Impact of ovarian stimulation on corpus luteum function and embryonic implantation. J Reprod Immunol 2002; 55:123.

(18) Colacurci N, Caprio F, La Verde E, Trotta C, Ianniello R, Mele D, De Franciscis P. Se-quential protocol with urinary-FSH/recombinant-FSH versus standard pro-tocol with recombinantFSH in women of ad-vanced age undergoing IVF. Gynecol Endo-crinol. 2014; 30(10): 730-3. (19) Nakamura K, Sheps S, Arck P. Stress and reproductive failure: past notions, present insights and future directions. J Assist Reprod Genet 2008; 25:47.

(20) Simonelli A, Guadagni R, De Franciscis P, Colacurci N, Pieri M, Basilicata P, Pedata P, Lamberti M, Sannolo N, Miraglia N. Envi-ronmental and occupational exposure to bi-sphenol $A$ and endometriosis: urinary and peritoneal fluid concentration levels. Int Arch Occup Environ Health. 2017; 90(1): 49-61.

(21) Siciliano RA, Mazzeo MF, Spada V, Facchiano A, d'Acierno A, Stocchero M, De Franciscis P, Colacurci N, Sannolo N, Miraglia N. Rapid peptidomic profiling of peritoneal fluid by MALDI-TOF mass spectrometry for the identification of biomarkers of endometriosis. Gynecol Endocrinol. 2014; 30(12): 872-6.

(22) Haimovici F, Anderson JL, Bates GW, Racowsky C, Ginsburg ES, Simovici D, Fichorova RN. Stress, anxiety, and depression of both 
partners in infertile couples are associated with cytokine levels and adverse IVF outcome. Am J Reprod Immunol. 2018; 79(4): e12832.

(23) Pereira N, Kucharczyk KM, Estes JL, Gerber RS, Lekovich JP, Elias RT, et al. Human papillomavirus infection, infertility, and assisted reproductive outcomes. J Pathog. 2015; 2015:578423578423.

(24) Schettino MT, Ammaturo FP, Labriola D, De Franciscis P, Colacurci N, Torella M. Betulinic acid and possible influence on the clearance of Human Papilloma Virus: cytological and virological follow-up. Minerva Ginecol. 2013; 65(6):661-8.

(25) Garolla A, Engl B, Pizzol D, Ghezzi M, Bertoldo A, Bottacin A, et al. Spontaneous fertility and in vitro fertilization outcome: new evidence of human papillomavirus sperm infection. Fertil Steril. 2016; 105(1): 65-72. e1.

(26) Schettino MT, Ammaturo FP, Grimaldi E, Legnante A, Marcello A, Donnarumma G, Colacurci N, Torella M. Persistent papillomavirus type- 31 and type- 45 infections predict the progression to squamous intraepithelial lesion. Taiwan J Obstet Gynecol. 2014; 53(4):494-7.

(27) De Franciscis P, Cobellis L, Fornaro F, Sepe E, Torella M, Colacurci N. Low-dose hormone therapy in the perimenopause. Int J Gynaecol Obstet. 2007 Aug;98(2):138-42

(28) Demyttenaere $\mathrm{K}$, Bonte L, Gheldof $\mathrm{M}$, Vervaeke M, Meuleman C, Vanderschuerem D, D'Hooghe T. Coping style and depression level influence outcome in vitro fertilization. Fertil
Steril. 1998; 69:1026.

(29) De Franciscis P, Guadagno M, Miraglia N, D'Eufemia D, Schiattarella A, Labriola D, et al. Follicular PB levels in women attending in vitro fertilization: role of endometriosis on the outcome. Ital J Gynaecol Obstet 2018; 30: 21-27. (30) Schettino MT, Gallo P, Rappa C, Coppola F, Tormettino B, Del Deo F, Grimaldi A, Torella M. Sexual function in patients who underwent surgery for stress urinary incontinence. Minerva Ginecol. 2014;66(4):355-63.

(31) Doblinger J, Cometti B, Trevisan S, Griesinger G. Subcutaneous Progesterone Is Effective and Safe for Luteal Phase Support in IVF: An Individual Patient Data Meta-Analysis of the Phase III Trials. PLoS One. 2016; 11(3): e0151388. (32) Vitale SG, Rossetti P, Corrado F, Rapisarda AM, La Vignera S, Condorelli RA et al. How to achieve high-quality oocytes? The key role of myo-inositol and melatonin. Int J Endocrinol. 2016; 2016: 4987436.

(33) Mancini M, Latini V, Scala RL, Balzi S, Pellegrini MG, Segatore MF et al. Medically Assisted Procreation: its risk in the maternal-fetal and neonatal pathology. Ital J Gynaecol Obstet. 2016; 28:9-17.

(34) Cozzolino M, Vitagliano A, Di Giovanni MV, Laganà AS, Vitale SG, Blaganje M, et al. Ultrasound-guided embryo transfer: summary of the evidence and new perspectives. A systematic review and meta-analysis. Reprod Biomed Online. 2018; 36(5): 524-542. 